Original paper UDC 111.84(045)

doi: $10.21464 / \mathrm{sp} 32101$

Received: November $29^{\text {th }}, 2016$

\begin{abstract}
Benedikt Paul Göcke
University of Oxford, Faculty of Theology and Religion, Ian Ramsey Centre for Science and Religion, Radcliffe Observatory Quarter, Woodstock Road, Oxford OX2 6GG, UK

benedikt.goecke@theology.ox.ac.uk
\end{abstract}

\title{
The Existence of Evil in Christian and Naturalistic Worldviews
}

\section{Abstract}

I clarify that an evil state of affairs is a state of affairs that satisfies the following conditions: (a) It entails the physical or mental suffering of a subject of experience, (b) it is morally inexcusable, (c) it does not lead to a greater good for the subject involved, and (d) the subject would prefer not to be in this state if it were fully capable to understand its situation. I argue that there are two different kinds of causes of evil: nature and free will. I show that there is no problem of evil implied by the existence of evil as such. I distinguish between problems of evil, solutions to problems of evil, and theories of evil. I argue that the existence of evil is problematic only for those worldviews that cannot provide a theory of evil. I argue that in contrast to naturalistic worldviews, Christian worldviews have the resources to successfully establish a theory of evil.
\end{abstract}

\section{Keywords}

evil, theory of evil, nature, free will, Christian worldview, naturalistic worldview

\section{What is Evil?}

Here are some assumptions I take for granted: First, a state of affairs $S$ is constituted by a particular $p$, a property $F$, and a point of time $t$. The obtaining of $S$ at $t$ consists in $p$ 's exemplifying $F$ at $t$. Second, a possible world $w$ is a maximally consistent state of affairs and the actual world is the only obtaining maximally consistent state of affairs. Third, the history $h$ of a possible world $w$ at $t$ is the temporally ordered class of all states of affairs that obtain in $w$ prior to and including $t$. The future $f$ of a possible world $w$ is the temporally ordered class of all states of affairs that obtain posterior to $t$.

Based on these assumptions I take it that evil is not a first-order property exemplifiable by particulars at certain points of time. There is neither empirical evidence nor a plausible metaphysical account on which evil is a first-order property that particulars could exemplify in the way they exemplify properties like having a certain size or shape. Despite this fact, evil is a property related to the obtaining of states of affairs: if there are two possible worlds, $w$ and $w^{*}$, which, at a particular point of time, have the same history and the same future, then the amount of evil in these worlds will be equal: evil, at least globally, supervenes on the property exemplifications of particulars. In other words, evil is a property that a state of affairs exemplifies in virtue of the fact that the particular constitutive of this state of affairs exemplifies the properties it exemplifies. 
The relevant particulars are a subject of experience. Subject of experience is an entity that is capable of being the subject of a stream of phenomenological being. The notion of phenomenological being is synonymous with the notion of experiences or qualia. The existence of one is necessary and sufficient for the existence of the other. In fact, there is no difference between being the subject of experience or qualia, and being the subject of phenomenological being. ${ }^{1}$ Therefore, a stream of consciousness is an entirety of experiences or qualia; it is what each of us takes to be his conscious life with all its experiential diversity, and precisely in this sense it is an entirety.

A world devoid of subjects of experience is the world devoid of evil. Therefore, the existence of subjects of experience is a necessary condition for the existence of evil. In other words, the existence of evil is of necessity related to the existence of consciousness. It is, however, only related to a particular class of mental properties. The class of mental properties to which evil is related to is the class of mental properties that entail the suffering of the subject of experience in question.

There are two kinds of suffering that may overlap: physical and mental. On the one hand, physical suffering is suffering the cause of which is an unnatural state of the body that prevents its normal functioning. Although it is difficult to specify the normal state of an individual body and its way of functioning, there are clear cases of physical suffering: If one of the extremities is cut off, if there is a virus, bacteria, or genetic defect leading to a severe malfunction of the body, then there is a clear case of physical suffering. ${ }^{2}$ On the other hand, mental suffering is suffering the cause of which is in the psyche of the individual. The range of mental suffering is the scope of psychological illnesses, even if there may be cases in which it is not clear whether the cause of mental suffering is physical or purely mental. ${ }^{3}$

Although every evil is grounded in the mental or physical suffering of a subject of experience, not every such suffering of a subject of experience is evil. First, if Richard wants to be the strongest human being in the world, this will involve hard training that may well cause him physical suffering. Suffering, therefore, can be acceptable to the subject of experience if the subject perceives it as a necessary means for a greater good. Second, if Richard relied heavily on the use of anabolic substances in order to foster the growth of his muscles, and gets caught by the police, the fine he receives - say he's going to jail for two months - is a state that can cause Richard to suffer mentally, maybe in the form of depression or existential anxiety. However, we would not judge Richard's sentence to be an evil state of affairs because it is morally excusable that he suffers in the way he does. The mere fact of suffering, therefore, is not a sufficient condition for the existence of evil.

A sufficient condition for the state of affairs to be evil is that a subject of experience suffers mentally or physically, although the cause of the suffering is neither morally justifiable nor leading to a greater good for the subject in question. If we subtract the suffering that is morally acceptable, and the suffering that does not lead to a greater good for the individual in question, only those instances of suffering remain that the subject in question has objective reason to prefer not to suffer from. An individual has objective reason to avoid these sufferings because it is objectively reasonable to avoid physical and mental suffering if it is not morally excusable nor leading to a greater good one wants to achieve.

Since, however, not every subject of experience is able to reflect with enough clarity on its present situation, since it might not have all the information 
needed to evaluate its situation objectively, and since, in the case of some subjects of experience, there might even be a lack of the necessary conceptual resources needed to come to clear judgement about the relevant situation, this sufficient condition needs qualification: a state of affairs is evil in virtue of the fact that the subject of experience suffers physically or mentally, there is no moral excuse for its suffering, neither a greater good to be achieved, and the subject of experience would want to avoid being in this state if it were able to understand its present situation, and if it were fully informed about it. ${ }^{4}$ For instance, a person that is constantly deceived about the true quality of its interpersonal relations suffers from evil in as much as the famous fawn that perishes in terrible suffering: both subjects of experience had objective reasons to avoid being in their situation, and therefore would prefer not to be in their situation, if fully informed about and capable to understand it. ${ }^{5}$

\section{What are the Causes of Evil?}

There are, in principle, two different kinds of causes of evil in the world: nature and free will.

The synonymy of those terms is also argued for by Chalmers. Chalmers is right in stating that 'experience' is a term in line with the notions of "'qualia', 'phenomenology', phenomenal', 'subjective experience', and 'what it is like'. Apart from grammatical differences, the differences among these terms are mostly subtle matters of connotation. 'To be conscious' in this sense is roughly synonymous with 'to have qualia', 'to have subjective experience', and so on. Any differences in the class of phenomena picked out are insignificant" (Chalmers 1996: 6). Pope and Singer (1978: 1) provide a rough circumscription of what belongs to the instance of consciousness thus understood: "The stream of consciousness - that flow of perceptions, purposeful thoughts, fragmentary images, distant recollections, bodily sensations, emotions, plans, wishes, and impossible fantasies - is our experience of life, our own personal life, from its beginning to its end."

2

The difficulty in agreeing on a biological definition of the normal function of body is due to the fact that "species are not static collections of organisms that can be 'preserved' against change like a can of fruit; they way and wane with every birth and death and their genetic complexions shift across time and space" (Juengst 2013: 50). As Caplan (2013: 202) says in respect to the biological nature of human beings, "is there a "nature' that is common to all humans, both those that exist now and that have existed in the past? The fight over whether there is any such thing as a human nature is a long-standing one (...). But one can concede that we have been shaped by a causally powerful set of genetic influences and selection forces and still remain sceptical as to whether these have produced a single 'nature' that all members of humanity possess. (...) If one surveys all humans, across cultures, those of all ages and varieties of congenital defects, and those from different times in the past it becomes hard to believe any single trait is defining of human nature".

3

If one presupposes a strictly reductive physicalist ontology, then mental suffering is ontologically reducible to physical suffering. In what follows, I suppose that at least prima facie there is an ontological difference between mental and physical suffering, and that there can be genuine mental causes of mental suffering.

4

There is the question whether a further condition for the specification of an evil state of affairs should be concerned with power. In most cases, a subject of experience that suffers from evil does not have the power to change its situation, at least not easily. If every evil state of affairs in which a subject suffers in the sense specified was under the control and power of the subject in question, then it seems that evil states of affairs would lose much of their horror. Perhaps, then, one could qualify the suggested definition as follows: the state of affairs has to be such that it is not in the control of the subject involved to change it.

5

Rowe (1979: 337) describes the fawn thus: "In some distant forest lightning strikes a dead tree, resulting in a forest fire. In the fire a fawn is trapped, horribly burned, and lies in terrible agony for several days before death relieves its suffering." 
Concerning nature: natural causes of evil are events the occurrence of which is not caused by a free decision of a free agent. Instead, they are caused unintentionally by physical, biological, or chemical particulars, their categorical and dispositional properties. They entail the obtaining of a state of affairs in which a subject of experience suffers in the sense specified above. ${ }^{6}$ Natural causes of evil operate on macroscopic, mesoscopic, and microscopic levels. Macroscopic natural causes of evil cause suffering for a whole population, mesoscopic natural causes lead to the suffering of parts of a population, and microscopic causes of evil only cause suffering for a particular individual. Macroscopic causes of evil entail mesoscopic and microscopic causes, but not the other way around.

Concerning free will: libertarian free will is a cause of evil in the sense that a free decision of a subject of experience leads to the obtaining of an evil state of affairs in which a subject of experience suffers in the sense explained above. Because, however, from an epistemological point of view, we can never take into account all of the consequences of our free decisions, and therefore are unable to know which states of affairs will in the future obtain as consequences of our free decisions, it seems plausible to reduce the number of morally relevant states of affairs to those states of affairs that can be addressed as immediately obtaining due to the intention of the free decision performed. ${ }^{7}$ As in the case of natural causes of evil, the scope of evil that is caused by free decisions of free agents can have a macroscopic, mesoscopic, and microscopic dimension: free decisions of a subject of experience can have effects on all or some members of a population, or only on a single individual.

If the world is determined, then all causes of evil are natural. If the world is indetermined and libertarian free will is real, then free will can be a cause of evil independent of natural causes of evil. Based on the assumption that the world is indetermined and that free will is real, it is evident that there is enormous suffering both caused by nature and free will. Natural causes lead to a variety of evil states of affairs on both mesoscopic and microscopic levels: on a mesoscopic level, natural catastrophes like earthquakes and tsunamis kill or injure millions of people the suffering of which is neither morally excusable, nor leads to a greater good for the individuals involved. The subjects of experience involved would have objective reasons to avoid being in their situation, and therefore would prefer not to be in their situation. The same is true at the microscopic level: genetic defects, viruses, and bacteria lead to immense amounts of suffering of individual people who would be right in wishing to avoid being in their situation if they were fully capable of understanding it. ${ }^{8}$ Next to natural causes of evil, free will very often is the cause of evil states of affairs: whether it is subjects of experiences freely deciding to kill or injure or torture other individuals, whether it is their betraying other individuals and their lying to them, the possibilities to freely cause evil are numerous and effect subjects of experience, so far, both on a mesoscopic and microscopic level.

\section{What is the Problem of Evil?}

The existence of evil states of affairs as such is not problematic: there is no contradiction entailed by the existence of evil states of affairs, as such, and it is a plain fact that the history of the actual world up to now is a history involving hideous amounts of evil caused both by nature and free will.

Of course, it is to a huge extent up to us to change the future of the actual world, and to drastically reduce the amount of evil. First, since we are free be- 
ings, we - that is, both any single one of us and we as a community - could act in a way that drastically reduces the evil caused by free decisions of human beings by acting in a responsible and morally right way. ${ }^{9}$ Second, through the use of the means developed by the modern sciences we could, in the not toofar away future, develop ways to prevent certain evils caused by nature both on the microscopic level dealing with genetic defects, viruses, and bacteria, and on the mesoscopic level that concerns natural catastrophes. ${ }^{10}$

To understand what is problematic about the existence of evil, we have to reflect briefly on the concept of worldviews. A worldview is a set of assumptions that shapes the way in which each one of us understands what is going in their life and in the world as a whole. It is in and through worldviews that we understand the phenomena that are present to us, both individually and collectively. Firstly, our individual and social life is influenced by our worldview. It shapes the way in which we understand phenomena and behave towards nature, one another, and ourselves. Secondly, on a global scale, the history of humankind can be addressed as a history of worldview generation, change, collapse, and conflict. ${ }^{11}$ There is literally no realm of human life that is independent from one's worldview. As Naugle rhetorically askes,

“... after all, what could be more important or influential than the way an individual, a family, a community, a nation, or an entire culture conceptualizes reality? Is there anything more profound or powerful than the shape and content of human consciousness and its primary in-

Cf. Göcke (2014) for an analysis of laws of nature in terms of physical particulars and their dispositions.

7

There is, of course, an element of fuzziness involved here. However, for our present purpose the definition of relevant states of affairs is enough to come to conclusions about the problem of evil.

8

Statements like this are often understood as leading to the question whether, therefore, the value of disabled people is downgraded. It may be argued that sometimes one does not want to change one's disability because it is experienced as a valuable part of one's narrative identity. What $\mathrm{I}$ have in mind is something like this: if, under a veil of ignorance, one could choose having a life with the disability or a life without it, then it seems objectively reasonable preferring not to have the disability, even if factually, if one has it, one's life is not to the slightest degree less valuable.

There is the question of what is morally right. However, for the purpose of this paper I bracket this question and assume an intuitive way of understanding, at least cum grano salis, which of one's actions are morally right and which are morally wrong.

10

This, of course, is part of the agenda of transhumanism. According to Marsen (2011: 86), "transhumanism is a set of dynamic and diverse approaches to the relationship between technology, self, and society. Since transhumanism is not a crystallized and static doctrine, [any] use of the term requires definition. The working definition that informs the subsequent discussion is this: transhumanism is a general term designating a set of approaches that hold an optimistic view of technology as having the potential to assist humans in building more equitable and happier societies mainly by modifying individual physical characteristics."

11

Just to mention a few examples: (a) religious worldviews are in conflict with one another. For instance, catholic and protestant worldviews differ in respect to their evaluation of reason as a means to support faith as well as in respect to their understanding of creaturely freedom and the role of the pope as head of the church. (b) Religious worldviews are in conflict with atheistic worldviews. Adherents of both worldviews disagree on the existence and relevance of God and supernatural entities as well as on the justification of moral values and the prospects of life after death. (c) Newtonian physics is in conflict with quantum mechanics. It is unclear whether the world is a deterministic world or whether there is genuine chance that our scientific theories have to account for. (d) Communist worldviews are in conflict with liberal worldviews. Both differ on the fundamental interpretation of the conditions necessary and sufficient for human social flourishing. 
terpretation of the nature of things? When it comes to the deepest questions about human life and existence, does anything surpass the final implications of the answers supplied by one's essential Weltanschauung?" (Naugle 2002: 345)

A worldview captures theory and practice both by way of providing an interpretational story of the origin, fundamental nature, future, and purpose of the universe and by way of implying what has to be done from an ethical point of view in order to foster the purpose of the universe. As Kim et al. argue,

“... our worldview forms the context within which we base our understanding of reality, knowledge, morality, and life's meaning and purpose. Our worldview has a profound impact on how we decide what is real versus unreal, what is right versus wrong, and what is important versus unimportant. It shapes our culture and expresses itself in all institutions including the arts, religion, education, media, and business." 12 (Kim et al. 2012: 205)

The existence of evil only becomes a problem if it is embedded into worldviews that, based on their principles and fundamental assumptions, entail that there is something problematic about the existence of evil.

We have to distinguish between problems of evil, solutions to problems of evil, and theories of evil: First, a problem of evil is an argument that, based on the existence of evil shows that fundamental assumptions of a particular chosen worldview either contradict the existence of evil, or turn out to be irrational or highly improbable. A problem of evil therefore is always a problem for the plausibility of a particular worldview, its account of the origin, purpose, and future of humanity and the universe as such. Because, if sound, a problem of evil shows that a particular worldview leads to contradiction, is irrational, or highly unlikely, and therefore should not be accepted as a worldview to live by. ${ }^{13}$

Second, a solution to a problem of evil is a response to this problem of evil that is formulated in terms of the worldview under attack and shows that, contrary to the problem of evil in question, the existence of evil does not lead to a contradiction with fundamental assumptions of the worldview in question, neither to the improbability nor the irrationality of its assumptions. A solution to a problem of evil is the defensive argument that shows the consistency of the existence of evil with the worldview in question. ${ }^{14}$

Third, a solution to the problem of evil is a necessary condition for, or an essential part of what I refer to as a theory of evil. A theory of evil accounts for the place of evil in the worldview in question in a positive way by showing that the existence of evil states of affairs is not only consistent but intelligible on the worldview in question in such a way that adherents of this worldview can relate in an intelligible and meaningful way to the existence of evil.

If there is a worldview in which a problem of evil can be formulated, then the worldview in question is in need of a solution to this problem of evil. If it cannot provide a solution to this problem of evil, then it will immediately lose its plausibility as a worldview to live by since it will have to accept that, depending on the problem of evil in question, it leads to contradiction, or is based on irrational or improbable assumptions. A mere solution to the problem of evil, however, will not suffice: If a worldview can provide solutions to problems of evil, it can show the consistency of the existence of evil with its assumptions but has left the very existence of evil states of affairs unaccounted for. This is to say that without a theory of evil the worldview in question cannot account for one of the existentially most troublesome facts about the world we are living in: that there is evil. Whatever else its merits are, a worldview that cannot account for one of the existentially most disturbing facts about the world, by this fact alone, loses much of its plausibility. Therefore, ceteris 
paribus, a worldview that has a theory of evil is more plausible to live by than a worldview that has no theory of evil.

\section{The Problem of Evil in Christian and Naturalistic Worldviews}

In what follows, I compare how problems of evil can be dealt with in Christian and naturalistic worldviews. I concentrate on these two worldviews because the problem of evil is traditionally discussed as an argument against the plausibility of Christian worldviews and because naturalistic worldviews, are often suggested, at least in this context, as worldviews of a higher plausibility.

\subsection{The Problem of Evil in Christian Worldviews}

First of all, there is no such thing as the Christian worldview; there are simply too many different denominations that refer to themselves as 'Christian' while at the same time the corresponding worldviews entail assumptions that are in conflict with presuppositions that are part of other Christian worldviews. For instance, according to some protestant Christian worldviews, there is no genuine human freedom because God's foreknowledge has already fixed what is going to happen in this world, and, consequently, who will be saved from a soteriological point of view. According to others, though, there is genuine human freedom that allows us to be the ones that determine our own fate. Furthermore, according to some Christian worldviews like the Roman-Catholic one, reason itself is a valuable way to support the overall Christian case, whereas other Christian denominations suppose that reason is fallen and that the only way to deal with God is by faith alone (sola fide).

However, although different Christian denominations vary in the precise formulation of their overall worldview, two things are clear. First, each Christian denomination is an all-encompassing worldview because each one attempts to provide "a complete understanding for the subject's known world and [tries] to introduce ways of living that encompass every aspect of life" (Carvalho 2006: 114). Second, although they differ as fully spelled out worldviews, there are certain fundamental assumptions without which no Christian worldview could be classified as Christian, and which consequently all Christian denominations share with one another. In what follows, I briefly mention four of them.

12

Cf. Sire 1997, Walsh and Middleton 1984 Apostel and Van der Veken (1991: 29-30) specify the following essential questions related to the analysis of worldviews: "(a) What is? Ontology (model of being), (b) Where does it all come from? Explanation (model of the past); (c) Where are we going? Prediction (model of the future); (d) What is good and evil? Axiology (theory of values), (e) How should we act? Praxeology (theory of action)". [trans. in Aerts et al. 1994, 25, quoted from Vidal (2012: 309)]

13

This assumes that a meta-criterion for the plausibility of a particular worldview consists in the fact that there are shared and universal standards of rationality. Although this assumption is highly controversial, I will assume it in what follows. As Vidal (2012: 318) says, "from a dialectical and second-order perspective, a philosopher can explore and understand a plurality of worldviews. But as she elaborates her first-order philosophical position, the same philosopher will still consider some worldviews to be better objectively, subjectively, or socially than others".

14

In more detail: a solution to a particular argument from evil shows that the existence of evil as it is used in the argument in question is consistent with the worldview under attack. Even if there is a solution to a particular problem of evil, there might be need for a different solution to a different problem of evil. 
First, the existence of God belongs to the core assumptions of any Christian worldview. If God does not exist, then there is no point in being a Christian. Second, God became human in Jesus of Nazareth, who was crucified and resurrected from the dead. If Jesus Christ did not exit, then there is no point in being a Christian, even if God exists. ${ }^{15}$ Third, there is life after death and each one of us will be judged according to the moral value of the life one has led (cf. Hebrews 9.27). ${ }^{16}$ Fourth, the plausibility of the idea that the way we lead our lives and build ourselves as persons with a particular character has an impact on our life after death presupposes that there are objective moral truths according to which we should direct our lives. ${ }^{17}$ On Christian faith, the Decalogue (Exodus 20: 1-17 and Deuteronomy 5: 4-21) and the Golden Rule (Matthew 7: 12) express some of the most fundamental objective moral truths that impose normative constraints on how we should behave.

If any of the aforementioned assumptions of a Christian worldview can be shown to be false, then there is no point in being a Christian. Problems of evil, though, are said to possess precisely this power to show that God does not exist or to show that belief in the existence of God is irrational.

There are many problems of evil discussed as arguments against the plausibility of Christian worldviews. Often a distinction is drawn between logical and evidential arguments from evil on the one hand, and between global and local problems of evil on the other. The second distinction does not replace the first: The first is about the strength of the conclusion, the second about kinds of evil found in the actual world.

Logical arguments from evil try to establish a logical contradiction between the existence of evil and the existence of God, whereas evidential arguments from evil attempt to show that the assumption that God exists is irrational or highly unlikely in light of the existence of evil. On the global argument from evil, the existence of God is incompatible with the huge amounts of horrendous evil we observe in the world: God, if he existed, would prevent all of these evils from occurring (cf. van Inwagen 2006: 56). On the local argument from evil, the existence of God is inconsistent with, or at least is highly improbable in the light of particular evils, that is, evils occurring at places and times that seem easily preventable by God since apparently no greater good depends on their occurrence (cf. van Inwagen 2006: 8). ${ }^{18}$

One of the important features of these different problems of evil, as they are discussed in analytic philosophy, is the assumption that God is the personal, eternal, omniscient, omnivolent, and omnipotent creator of the universe ex nihilo, who can interfere in the history of the actual world, in principle, at any time. This God of Christianity, it is argued, by his omnipotence could prevent evil, by his omniscience would know all the evil in the world, and by his omnivolence would want to prevent the occurrence of evil states of affairs. ${ }^{19}$ Since, however, this is not what we observe, neither on a small nor a large scale, it is concluded that the assumption that this God exists either leads to contradiction (logical argument from evil), or turns out to be highly unlikely or irrational (evidential argument from evil).

Christians have to formulate solutions to these problems of evil and to elaborate corresponding theories of evil that account for the fact that the Christian God creates a world that is open to the existence of evil, and for the fact that God does not interfere to nullify evil states of affairs when they are about to occur. $^{20}$

A valuable starting point for a solution to the problem of evil is this: Christian worldviews are committed to the existence of a personal ultimate ground 
of reality that is worthy of worship and has revealed Himself to His people on various occasions. Apart from this general commitment, however, there is hardly any unanimity amongst Christians how to spell out the Christian concept of God both in a philosophically and theologically adequate way. Because neither the Bible nor philosophical speculation specifies unambiguously the Christian concept of God, it is no surprise that there is a huge variety of concepts of God that is consistent with the fundamental assumptions of a Christian worldview. The assumption that an adequate concept of the Christian God is the concept of God as specified in the premises of the various arguments from evil, therefore, is by no means an essential assumption of Christian worldviews. ${ }^{21}$

Although there is a variety of plausible Christian concepts of God, I suppose for the sake of argument that the concept of God mentioned above needs revision. I assume that God is not eternal, but everlasting: God exists in time,

15

As McGrath (1991: 289) says: "Christians regard Christ as authoritative because, in the end, they recognize him to be none other than God himself, coming among us as one of us. The authority of Christ rests in his being God incarnate. His teaching is lent dignity, weight and authority by his identity. And that identity can only be spelled out fully by the doctrine of the person of Christ. Christian principles thus rest on Christian doctrine."

16

Although it is controversial whether life after death is best accounted for in terms of an immortal immaterial soul or in terms of bodily resurrection (cf. Murphy 2006), and although it is a matter of on-going theological dispute how precisely judgement day is supposed to work, and how drastic the judgement might be, the assumptions that there is a life after death and that something will happen that is related to our lives are essential parts of Christian faith.

17

Without the assumption that there are objective moral truths, the idea that our behaviour in this life matters for our life after death becomes entirely meaningless: how could we be judged in a fair divine trial from a moral point of view if there are no objective moral truths to begin with?

18

Next to these philosophical problems of evil, there are also psychological problems of evil that concern how evil is dealt with by a single individual that suffers from evil. The psychological problem of evil follows from the philosophical problem of evil: if there is a solution to the problem of evil and a theory of the problem of evil, then these can be taken as a psychological help to deal with evil on the individual level, at least if the sufferer is an adherent of the worldview in question.
19

Cf. Mackie (1955: 200) for a clear formulation of the logical problem of evil: "In its simplest form the problem is this: God is omnipotent; God is wholly good; and yet evil exists. There seems to be some contradiction between these three propositions, so that if any two of them were true the third would be false. But at the same time all three are essential parts of most theological positions: the theologian, it seems, at once must adhere and cannot consistently adhere to all three."

20

In theological contexts, solutions and theories of evil are referred to as defences or theodicies. I prefer to speak of solutions and theories because these terms are applicable to worldviews other than Christian worldviews. Cf. Van Inwagen (2002: 30): "A 'defense' in the weakest sense in which the word is used is an internally consistent story according to which God and evil both exist. Sometimes the following two requirements are added: The evil in the story must be of the amounts and kinds that we observe in the actual world, and the story must contain no element that we have good scientific or historical reasons to regard false. A theodicy is a story that has the same internal features as a defense, but which the theodicist, the person telling the story, puts forward as true or at least highly plausible.". Furthermore: "A defence will ascribe to God some reason for allowing the possibility of evil in his creation (for example, creaturely free will is a very great good, a good so great that its existence justifies the risk of its possible abuse). It will go on to say that this source, whatever it may have been, produced not just some evil, but vast amounts of horrendous evil, and it will, finally, ascribe to God another reason for not simply removing from his creation by fiat the vast amounts of evil that issued from the Source of Evil, a reason for allowing the vast amounts of horrendous evil produced by the Source to continue to exist." (Van Inwagen 2001: 66-67) 
not outside of time. I assume that God does not know future contingents and therefore, apart from necessary truths, does not know the future of the actual world. Consequently, I assume that the future of the actual world can influence God. This variation of what is known as open theism is both consistent with the Bible and philosophical reflections on the ultimate ground of empirical reality.

Based on this concept of God, the existence of evil can be dealt with in a first step by providing a sufficient reason God has to create a world that is open to the existence of evil. ${ }^{22}$ A world that is open to the existence of evil is a world in which evil states of affairs can occur. If God has sufficient reason to create a world that is open to the existence of evil, then he has reason to accept that evil might indeed come into existence and therefore he can in principle accept the existence of evil should it occur. To elucidate this reason, two interwoven assumptions have to be taken into account: that libertarian free will is real, and that the world is a reliable place to live in. The world is a reliable place to live in if the natural processes that occur in the history and future of the actual world can be formulated in an intelligible way.

These assumptions are important because it is only possible worlds in which free will is real and in which the universe is a reliable place that a meaningful live is possible. Without free will, life is meaningless. Without a reliable nature, free will is impossible: We can only act freely in a world which is regulated by laws of nature, but not determined by laws of nature. Only this enables us to be aware of what we can do in which circumstances, and to know what the consequences of our actions will be, both of which are necessary presuppositions for libertarian free will. ${ }^{23}$

If God wants to create a world in which a meaningful live and responsible action is possible, he has no choice other than creating a world that entails libertarian free will and regular laws of nature. A world that entails libertarian free will and regular laws of nature, however, eo ipso is a world that is open to the existence of evil because free will can be used to cause the obtaining of evil states of affairs and because due to the regularity of the laws of nature it may well happen that nature turns out to be a cause of evil. Therefore, if he wants to create a world in which a meaningful live is possible, God has no choice but creating a world that is open to the existence of evil. Since the creation of a world in which a meaningful life is possible is of intrinsic value, it follows that God has an objectively sound reason to create a world that is open to the existence of evil. ${ }^{24}$ The existence of evil as such is not inconsistent with the existence of God.

Although the existence of evil as such is consistent with the existence of God and although there is a reason for God to create a world that is open to the existence of evil, this does not explain why God does not prevent the existence of evil when he knows that evil is about to occur in the world. In principle, God could prevent any single instance of evil, but he could do so only by destroying the very possibility that this world enables a meaningful life, based on free will, and the regularities of the laws of nature. Therefore, God cannot prevent every single instance of evil without obtaining a contradiction in regard to his plan to create a world that enables a meaningful life. However, it still seems that there are countless evil states of affairs obtaining at places and times that God could have easily prevented without corruption of his purpose to create a world in which a meaningful life is possible. ${ }^{25}$

This, the local problem of evil, presupposes that there is a finite set $M$ of evil states of affairs that satisfies the following conditions: (a) God could prevent 
the obtaining of the states of affairs that are elements of $M$ without thereby destroying the possibility of a world that sustains a meaningful life and (b) if God prevented the existence of an evil state of affairs that is not an element of $M$, then he would destroy the possibility that this world sustains a meaningful life.

To solve this problem of evil, the Christian can point out two problems with its presupposition: First, we do not know whether it is possible that there is such a set. Any cardinality we could suggest would be arbitrary. Second, if there is no such set, then God cannot be blamed for not preventing particular evils. If there is such a set, then God will know its cardinality even if we do not know it. But then God in fact already prevents all the evils he can prevent. Therefore, either the presupposition of this argument from evil is beyond epistemic confirmation or false because God in fact prevents all the evil states of affairs he can prevent. ${ }^{26}$

The existence of evil is consistent with the existence of the Christian God. It neither leads to contradiction, nor lowers the probability of God's existence, or the rationality of believing in God's existence. There is, though, one crucial element missing for a complete Christian theory of evil. This element is an

21

Cf. Wildman (2009: 616): "The varieties of [theism] run from process theism to deism, and form the philosophical subtleties of Boston Personalism to the dualistic hypostatization of human experiences of pleasure and pain in Zoroastrianism and Manichaeism." Bishop (1998: 174) is right when he suggests that this Omni-God conception is wrongly presupposed by many in the discussion to be the only available concept of God: "Can it be consistent to adhere to theism, and yet to reject the belief that omniGod exists, where 'omniGod' means a unique omnipotent, omniscient, omnibenevolent, supernatural person who is creator and sustainer of all else that exists? On the assumptions prevailing within Philosophy of Religion, at least as practised by analytical philosophers, the answer is clearly 'No'. Such philosophers typically presuppose that theism virtually by definition requires belief that omniGod exists."

22

Since God is subject to the same standards of reason and rationality that we are subjected to, it follows that if we know that y could be a sufficient reason for God to do $\mathrm{x}$, then $\mathrm{y}$ is a sufficient reason for God to do $\mathrm{x}$.

23

As Swinburne (2010: 86) says, "the free-will defence claims that it is a great good that humans have a certain sort of free will which I shall call free and responsible choice, but that, if they do, then necessarily there will be the natural possibility of moral evil". Cf. also Swinburne (2010: 94-95): "Natural evil is not to be accounted for along the same lines as moral evil. Its main role rather, I suggest, is to make it possible for humans to have the kind of choice which the free-will defence extols. There are two ways in which natural evil operates to give humans those choices. First, the operation of natural laws producing evils gives humans knowledge (...) of how to bring about such evils themselves. (...) Natural processes alone give humans knowledge of the effects of their actions without inhibiting their freedom, and if evil is to be a possibility for them they must know how to allow it to occur. The other way in which natural evil operates to give humans their freedom is that it makes possible certain kinds of action towards it between which agents can choose. (...) A particular natural evil, such as physical pain, gives to the sufferer a choice - whether to endure it with patience, or bemoan his lot. (...) The pain makes possible these choices, which would not otherwise exist."

24

One might argue that life is not of intrinsic value. However, Christians assume that life is indeed of intrinsic value.

25

As van Inwagen (2006: 8) says, "local arguments from evil are arguments that appeal to particular evils - the Holocaust maybe, or the death of a fawn, unobserved by any human being, in a forest fire - and proceed by contending that a benevolent and omnipotent God would not have allowed that particular evil to occur".

26

It should be clear that we cannot know which evil states of affairs God in this case prevents. They do not obtain as parts of the actual world and therefore escape our intellectual or experiential access. 
answer to the question: "What happens to those who in this world suffer from evil? How can they bear their situation existentially?"

Although we have seen that on Christian worldview on the existence of evil is consistent with the existence of God, and although there is argument that God cannot prevent more evil than he does without the destruction of the possibility of a meaningful life, the fact that some subjects of experience suffer terribly from evil, despite its rationale, prima facie has a bad taste to it. It may be argued that knowledge of the fact that God cannot prevent their suffering is of little relief to those who do indeed suffer from evil.

However, Christian worldviews have the resources to account for this situation both from a Christological and a soteriological point of view. From a Christological point of view, God became human in Jesus Christ. Jesus Christ died for us on the Cross. God knows suffering and evil first hand, but the resurrection of Jesus Christ shows that God surmounted evil through love. Therefore, from a soteriological point of view, evil, ultimately, is without substance and the evil we are subject to will be redeemed and atoned for by God.

On Christian worldviews, the ontological place where this will happen is life after death, where God will judge upon the moral quality of our life. Evil, although at present existing and pressing, in the long run will play no role and is atoned for by God. In the broader context of Christian worldviews, this theory of evil helps the Christian to accept his sufferings as a flicker in the story of his eternal life that through the love and grace of God will be surmounted and atoned for. This theory of evil does not take away the pain one endures when suffering from evil, but it helps to address it as something that from the soteriological point of view has already been surmounted by God. It therefore can be of help to psychologically relate to the existence of evil in a way that finds a place for evil other than ultimate absurdity.

\subsection{The Problem of Evil in Naturalistic Worldviews}

Although similar to Christian worldviews, it is not the case that there is something like the naturalistic worldview. I assume that naturalistic worldviews entail that no supernatural entities exist. All that exists is nature and its inhabitants. Naturalistic worldviews are consistent both with the assumption that the world is determined, and the assumption that the world is indetermined. Naturalistic worldviews assume that the natural sciences, ultimately, are the only way to obtain knowledge of the world and its fundamental structure.

When it comes to existence of evil and naturalistic worldviews, the first problem consists in the fact that it is not evident that naturalistic worldviews have the resources to account for the very existence of evil states of affairs. The definition of evil states of affairs suggested above entails the existence of objective moral values and objective moral truths: Those states of affairs are evil that, although they entail suffering, are not morally excusable. Therefore, to be able to address the obtaining of some states of affairs as evil, the naturalist has to accept that there are objective moral values or at least he has to accept that there are objective moral norms that can be used to classify the obtaining of a state of affairs as evil. But the naturalist can only account for these if he rejects the assumption that the natural sciences, which are merely descriptive, are the only way to obtain knowledge. Therefore, either the naturalist has to bite the bullet and to claim that there are no evil states of affairs - which, by all means, is absurd as part of a worldview to live by - or has to assume that there is objective morality. 
Based on the assumption of objective morality, however, it seems as if no further problem of evil could be formulated for naturalistic worldviews: Prima facie there is nothing in a naturalistic worldview that seems likely to be troublesome when connected to the existence of evil: The naturalist can accept that indeed nature and free will are causes of evil in the world. He can argue that it is up to us to reduce the suffering caused by free will and by nature. He can argue that those who suffer from evil are indeed in an unfortunate situation. He can argue that there is no ultimate reason whatsoever why we are living in a world that is open to the existence of evil: There cannot be an ultimate reason for this because a reason would presuppose a supernatural and personal creator of the world who acts for this reason in creating the world. Prima facie, then, naturalistic worldviews do not seem to have a problem of evil.

However, although on naturalistic worldviews no problem of evil can be stated that is structurally analogous to the problems of evil discussed in the context of Christian worldviews, the naturalist is troubled by a far bigger problem: he cannot elaborate a satisfying theory of evil. That is, naturalism cannot deal with the existence of evil in the way needed for naturalism to be a plausible worldview to live by. On naturalistic premises, because there is no life after death and no God, there cannot be atonement for the suffering endured in this life: Subjects of experience that suffer from evil, suffer from evil, and that is the end of the story. All suffering from evil is, metaphysically and morally, in vain. One of the existentially most troublesome facts, on naturalistic worldviews, therefore cannot be accounted for in a way that enables the naturalist to find an intelligible place for evil in the world at all.

\section{The Implausibility of Naturalism}

Prima facie Christian worldviews are confronted with a variety of problems of evil. However, they have the resources to solve these problems and they are able to establish a rational theory of evil that explains why evil exists in the world, why some subjects of experience suffer from evil, and why evil ultimately is without substance and will be atoned for by God. Naturalistic worldviews are not confronted with problems of evil structurally similar to the problems that the Christian has to deal with. Naturalistic worldviews either deny the existence of evil because they deny objective morality or they assume that although there is objective morality suffering from evil is bad luck, in vain, and never atoned for.

Now, based on the assumption that apart from the existence of evil both Christian and naturalistic worldviews have good arguments supporting their overall case as worldviews to live by, the existence of evil turns out to be an argument for the implausibility of naturalistic worldviews when compared to the plausibility of Christian worldviews.

In contrast to naturalistic worldviews, Christian worldviews have a theory of evil that enables them to address the suffering from evil in a way 'that puts evil in its place'. And it is not only the hope for an eternal life that motivates the Christian's theory of evil. The very concept of objective morality suggests that the intelligibility of objective morality presupposes that, ultimately, justice will be done and that those who suffer from evil will be brought into a state in which their suffering is atoned for. Since, however, this is not what we observe in this world, the belief that there is a life after death where this state will be established is a strong and rational feature of the possibility of a 
moral life and therefore a plausible feature of a moral worldview to live by. As Kant says:

"Morality in itself constitutes a system, but happiness does not, except insofar as it is distributed precisely in accordance with morality. This, however, is possible only in the intelligible world, under a wise author and regent. Reason sees itself as compelled either to assume such a thing, together with life in such a world, which we must regard as a future one, or else to regard the moral laws as empty figments of the brain, since without that presupposition their necessary success, which the same reason connects with them, would have to disappear. Hence everyone also regards the moral laws as commands, which, however, they could not be if they did not connect appropriate consequences with their rule a priori, and thus carry with them promises and threats. This, however, they could not do if they did not lie in a necessary being, as the highest good, which alone can make possible such a purposive unity." (Kant CpR B 838)

If Christian and naturalistic worldviews are on a par regarding their overall justification the treatment of the existence of evil in Christian and naturalistic worldviews leads to the recognition that a Christian worldview is a more plausible worldview to live by than a naturalistic worldview. The existence of evil is only prima facie a problem for Christian worldviews. Secundia facie it shows the implausibility of naturalism as a worldview to live by.

\section{Bibliography}

Aerts, Diederick et al. (1994): World Views: From Fragmentation to Integration. Brussels: VUB Press.

Apostel, Leo; Van der Veken, Jan (1991): Wereldbeelden: van fragmentering naar integratie. Kapellen: DNB/Pelckmans.

Bishop, John (2009): "Towards a Religiously Adequate Alternative to OmniGod Theism". In: Sophia 48 (2009), pp. 419-433. doi: https://doi.org/10.1007/s11841-009-0130-7.

Caplan, Arthur L. (2013): “Good, Better, or Best?”. In: Savulescu, Julian; Bostrom, Nick (eds.): Human Enhancement, pp. 199-209. Oxford: Oxford University Press.

Carvalho IV, John J. (2006): "Overview of the Structure of a Scientific Worldview". In: Zygon 41 (1/2006), pp. 113-124. doi: https://doi.org/10.1111/j.1467-9744.2006.00729.x.

Chalmers, David (1996): The Conscious Mind: In Search of a Fundamental Theory. Oxford: Oxford University Press.

Göcke, Benedikt Paul (2014): "Did God Do It? Metaphysical Models and Theological Hermeneutics". In: International Journal for Philosophy of Religion 78 (2/2014), pp. 215231. doi: https://doi.org/10.1007/s11153-014-9489-7.

van Inwagen, Peter (2006): The Problem of Evil. Oxford: Oxford University Press. doi: https://doi.org/10.1093/oxfordhb/9780195331356.003.0009.

van Inwagen, Peter (2002): “What is the Problem of the Hiddenness of God?". In: HowardSnyder, Daniel; Moser, Paul K. (eds.): Divine Hiddenness. New Essays, pp. 24-32. Cambridge: Cambridge University Press.

van Inwagen, Peter (2001): "The Argument from Particular Horrendous Evils". In: American Catholic Philosophical Association, ACPA Proceedings 74 (2001), pp. 65-80.

van Inwagen, Peter (1988): “The Magnitude, Duration, and Distribution of Evil: A Theodicy”. In: Philosophical Topics 16 (2/1988), pp. 161-187. doi: https://doi.org/10.5840/ philtopics198816218.

Juengst, Eric T. (2013): “What's Taxonomy Got to Do with It? 'Species Integrity', Human Rights, and Science Policy”. In: Savulescu, Julian; Bostrom, Nick (eds.): Human Enhancement, pp. 43-58. Oxford: Oxford University Press. 
Kim, David; McCalman, David; Fisher, Dan (2012): "The Sacred/Secular Divine and the Christian Worldview". In: J Bus Ethics 109 (2/2012), pp. 203-208. doi: https://doi. org/10.1007/s10551-011-1119-Z.

Mackie, John Leslie (1955): “Evil and Omnipotence”. In: Mind 64 (254/1955), pp. 200-212. doi: https://doi.org/10.1093/mind/lxiv.254.200.

Marsen, Sky (2011): "Playing by the Rules-or not? Constructions of Identity in a Posthuman Future”. In: Hansell, Gregory R.; Grassie, William (eds.): Transhumanism and its Critics, pp. 84-93. Philadelphia, PA: Metanexus Institute.

McGrath, Alister E. (1991): "In What Way can Jesus Be a Moral Example for Christians?". In: JETS 34 (3/1991), pp. 289-298.

Murphey, Nancey (2006): Bodies and Souls, or Spirited Bodies?. Cambridge: Cambridge University Press. doi: https://doi.org/10.1017/cbo9780511802805.

Naugle, David K. (2002): Worldview: The History of a Concept. Grand Rapids: B. Eerdmans Publishing.

Pope, Kenneth S.; Singer, Jerome L. (eds.) (1978.): The Stream of Consciousness: Scientific Investigations into the Flow of Human Experience. Chichester: Wiley.

Rowe, William L. (1979): “The Problem of Evil and Some Varieties of Atheism”. In: American Philosophical Quarterly 16 (4/1979), pp. 335-341.

Sire, James W. (1997): The Universe Next Door. A Basic Worldview Catalogue. Dowers Grove, IL: Intervarsity Press.

Swinburne, Richard (2010): Is There a God?. Oxford: Oxford University Press

Vidal, Clément (2012): "Metaphilosophical Criteria for Worldview Comparison". In: Metaphilosophy 43 (3/2012), pp. 306-347. doi: https://doi.org/10.1111/j.1467-9973.2012.01749.x.

Walsh, Brian J.; Middleton, J. Richard (1984): The Transforming Vision: Shaping a Christian Worldview. Downers Grove, IL: Intervarsity Press.

Wildman, Wesley J. (2009): “Ground-of-Being-Theologies”. In: Clayton, Philip; Simpson, Zachary (eds.): The Oxford Handbook of Religion and Science, pp. 612-633. Oxford: Oxford University Press. doi: https://doi.org/10.1093/oxfordhb/9780199279272.003.0037.

\section{Benedikt Paul Göcke}

\section{Postojanje zla u kršćanskim} i naturalističkim svjetonazorima

\section{Sažetak}

Razjašnjavam da se za zlo stanje stvari može reći da je zlo stanje stvari kada zadovoljava sljedeće uvjete: (a) uključuje tjelesnu ili mentalnu patnju subjekta iskustva, (b) moralno je neopravdivo, (c) ne vodi do većeg dobra upletenog subjekta $i$ (d) kada bi subjekt imao potpuno razumijevanje situacije, onda bi preferirao da se u takvomu stanju ne nalazi. Argumentiram da postoje dvije vrste uzroka zla: priroda i slobodna volja. Pokazujem da problem zla ne postoji strogo na temelju postojanja zla. Postavljam razliku između problema zla, rješenja problema zla i teorije zla. Argumentiram da je postojanje zla problematično samo za onakve svjetonazore kakvi ne mogu osigurati teoriju zla. Suprotno naturalističkim svjetonazorima, kršćanski svjetonazor ima uvjete za uspješnu uspostavu teorije zla.

\section{Ključne riječi}

zlo, teorija zla, priroda, slobodna volja, kršćanski svjetonazor, naturalistički svjetonazor 


\section{Benedikt Paul Göcke}

\section{Existenz des Bösen in christlichen und naturalistischen Weltanschauungen}

\section{Zusammenfassung}

Ich stelle klar, dass man einen Zustand der Beziehungen, der böse ist, als einen bösen Zustand der Beziehungen charakterisieren kann, falls folgende Bedingungen erfüllt werden: (a) Der betreffende Zustand bezieht das körperliche oder mentale Leiden des Subjekts der Erfahrung ein, (b) Er ist moralisch nicht zu rechtfertigen, (c) Er führt nicht zum größeren Wohl des involvierten Subjekts und (d) Hätte das Subjekt das vollkommene Verständnis der Situation, würde es dann bevorzugen, sich nicht in einem solchen Zustand zu befinden. Ich argumentiere, dass es zwei Arten von Ursachen des Bösen gibt: die Natur und der freie Wille. Ich zeige, dass das Problem des Bösen nicht strikt auf der Grundlage der Existenz des Bösen besteht. Ich setze den Unterschied zwischen dem Problem des Bösen, der Lösung des Problems des Bösen und der Theorie des Bösen. Ich argumentiere, die Existenz des Bösen sei lediglich für solcherart Weltanschauungen problematisch, die keine Theorie des Bösen liefern können. Entgegen den naturalistischen Weltanschauungen verfügt die christliche Weltanschauung über die Voraussetzungen für eine erfolgreiche Etablierung der Theorie des Bösen.

\section{Schlüsselwörter}

Böses, Theorie des Bösen, Natur, freier Wille, christliche Weltanschauung, naturalistische Weltanschauung

\section{Benedikt Paul Göcke}

\section{L'existence du mal dans les visions du monde chrétienne et naturaliste}

\section{Résumé}

Je clarifie le fait que pour la situation qu'est le mal, il est possible de dire que le mal est un état des choses lorsqu'il répond aux conditions suivantes: (a) il inclut une douleur physique et mentale pour le sujet de l'expérience, (b) il est injustifiable d'un point de vue morale, (c) il ne mène pas à un plus grand bien pour le sujet en question, (d) si le sujet avait une pleine compréhension de la situation, il préférerait alors ne pas se trouver dans une telle situation. J'argumente en faveur de l'existence de deux causes du mal : la nature et le libre-arbitre. Je montre que le problème du mal n'existe pas de manière absolue sur la base de l'existence du mal. Je pose une différence entre le problème du mal, la résolution du problème du mal et la théorie sur le mal. J'argumente que l'existence du mal est problématique uniquement pour les visions du monde qui ne peuvent assurer une théorie du mal. Contrairement aux visions du monde naturaliste, la vision du monde chrétienne comporte les conditions pour l'établissement d'une théorie du mal efficace.

\section{Mots-clés}

mal, théorie du mal, nature, libre-arbitre, vision du monde chrétienne, vision du monde naturaliste 